\title{
A Workers' Cold War in the Quad Cities: \\ The Fate of Labor Militancy in the Farm Equipment Industry, 1949-1955
}

\author{
MATTHEW M. METTLER
}

BEGINNING IN 1949, the Quad Cities of Iowa and Illinois were, in the words of one newspaper reporter, the "scene of the country's largest union war." ${ }^{1}$ That war was, in fact, a protracted civil war within the Congress of Industrial Organizations (CIO) to define the future of American industrial unionism. As the Cold War deepened, the unions that composed the CIO disagreed over how best to maintain strength in the face of a renewed business and government assault on labor unions and the militant tactics they had employed in the 1930s. By 1949, eleven left-led unions that represented more than one million workers and defended militant trade union practices had left or had been forced out of the CIO. Those unions immediately became recruiting targets of the remaining $\mathrm{CIO}$ unions. The ensuing conflict between rival industrial labor unions surfaced throughout the country, but rarely was the conflict as enduring and violent as it was in the Quad Cities, where the United Auto Workers (UAW) engaged in a sustained effort to raid and gain jurisdiction over all farm implement workers in the left-led Farm Equipment and Metal Workers of America (FE).

1. Moline Daily Dispatch, 2/10/1949.

THE ANNALS OF IOWA 68 (Fall 2009). (c) The State Historical Society of Iowa, 2009. 
At stake in this raiding war was the future of the strong current of militant industrial unionism in the farm equipment plants of the Quad Cities. Rank-and-file support for the FE remained strong after the union's expulsion from the CIO and its subsequent merger with the United Electrical, Radio, and Machine Workers (UE) in late 1949, but a devastating strike at International Harvester in 1952 and a poor contract helped build support for the UAW. ${ }^{2}$ By 1954 the UAW had succeeded in taking the largest FE-UE locals at International Harvester, and by 1955 the remaining locals had disaffiliated as a group from the UE and voted on a local-by-local basis to affiliate with either the UAW or the International Association of Machinists.

Drawing mainly from union archives, press coverage, and oral histories from participants, this article will set these events in context and assess the rationale of the FE-UE locals as they gradually chose to leave their militant left-led union in favor of more conservative mainstream unions. The desertion of the FEUE may appear to be evidence of the rank-and-file's conservatism and rejection of the core ideals of left-led unionism; the move toward mainstream unionism is better understood, however, as a difficult but pragmatic attempt to preserve those core ideals. For the purpose of this study, the core ideals of labor militancy include the high value placed on rank-and-file democracy, local autonomy, an active shop-floor presence of union stewards, and a bargaining approach that sought to increase workers' control of production and profit through conflict rather than cooperation with management.

All too often historical accounts of the CIO's ideological and organizational shift from democratic labor militancy to bureaucratic centrism following World War II gloss over the extraordinary conflict surrounding the transition. Such analysis is in part grounded in a school of thought that finds labor militancy to be transient in the complex American working-class consciousness, a refuge of last resort for workers in dire economic straits. That interpretation suggests that as the Great Depression gave way to the affluence and security of the postwar era, workers were satisfied with the rise in their standard of living and thus dropped

2. After the FE and UE merged in 1949, all FE locals adopted a split acronym: FE-UE. 
their allegiance to left-led unions. Labor historian Michael Kazin cites this postwar moment as the end of the CIO as a social movement; workers, "grateful for union protection . . . could now leave the marching and sloganeering to others." Historian Robert H. Zieger cuts to the heart of this interpretation in the conclusion to his comprehensive study of the CIO: "I do not believe that there was a leftward-tending working-class militancy in the 1930s that CIO bureaucracy defanged or diverted." ${ }^{3}$

On the other end of the spectrum are labor historians who argue that the postwar CIO bureaucracy did exactly that: the movement toward bureaucracy and centrism, they argue, ceded labor's strength for short-term gains and laid the foundation for the ensuing decline of the labor movement. So-called new labor historians in the 1960s and 1970s established the argument that a leftward tendency in the working class can be understood as a resurgence of an enduring producerist ideal. That ideal matured during the massive industrialization of the late nineteenth century as mechanization and the division of labor began to distance workers from the fruits of their labor. ${ }^{4}$ The legacy of producerism can be found in social democratic politics, but also in workplace-centered syndicalism. This latter tradition guided workers to embrace militant tactics such as work stoppages to reassert their control over the production process. Producerist

3. Michael Kazin, The Populist Persuasion: An American History (Ithaca, NY, 1998), 162; Robert H. Zieger, The CIO, 1935-1955 (Chapel Hill, NC, 1995), 376. Besides Kazin's, notable studies stressing the lack of popular support for (or the fleeting nature of) militant unionism during the period under examination include Bill Goode, Infighting in the UAW: The 1946 Election and the Ascendancy of Walter Reuther (Westport, CT, 1994); Bert Cochran, Labor and Communism: The Conflict that Shaped American Unions (Princeton, NJ, 1977); and Harvey A. Levenstein, Communism, Anti-Communism, and the CIO (Westport, CT, 1981).

4. Significant studies informing this argument during the period under examination include Stephen Meyer, "Stalin over Wisconsin": The Making and Unmaking of Militant Unionism, 1900-1950 (New Brunswick, NJ, 1992); Halpern, UAW Politics in the Cold War Era; Steve Rosswurm, ed., The CIO's Left-Led Unions (New Brunswick, NJ, 1992); Nelson Lichtenstein, Labor's War at Home: The CIO in World War II (Cambridge, 1982); and idem, Walter Reuther: The Most Dangerous Man in Detroit (New York, 1995). The contemporary consequences of the decline in labor militancy are captured well in Steve Fraser and Gary Gerstle, eds., The Rise and Fall of the New Deal Order, 1930-1980 (Princeton, NJ, 1989), esp. Nelson Lichtenstein's essay, "From Corporatism to Collective Bargaining: Organized Labor and the Eclipse of Social Democracy in the Postwar Era," 122-52. 
syndicalism found renewed enthusiasm among workers under the banner of industrial democracy during World War I and resurfaced in the 1930s CIO in calls for rank-and-file democracy. ${ }^{5}$

This article is informed more by the latter group of historians who stress the continuity of producerism, but I aim to avoid the polarized nature of this debate in two ways. First, the scope of my research and analysis is local and is intended to provide only a fragmentary but important piece of a much larger narrative. Historians' focus on the powerful swath of national Cold War labor politics tends to overshadow the broad range of local struggles that compose a complex tapestry of working-class experience. To this end, this article adds to a trend in the historical study of labor and the Cold War that confines its scope to localities.

Second, my research on the Quad Cities has led me to stress the divide between the economic and political/social components of left-led unionism. Left-led industrial unions such as the FE and UE adhered to producerist trade union principles, but also espoused progressive social causes regarding racial and gender equity and a foreign policy critical of the prevailing U.S. foreign policy. As Gerald Zahavi has suggested in his work on militant UE locals in Schenectady, New York, producerism and progressive social politics were often mutually exclusive in the minds of workers, but not in their left-led unions. Zahavi uses the concept of "right-wing Communists" to describe a segment of workers who were committed to "traditional rank-and-file concerns" regarding their union's economic practice, but wavered when the progressive social agenda of left-wing Commu-

5. On the roots and legacy of producerism, see Shelton Stromquist, "The Crisis of 1894 and the Legacies of Producerism," in Richard Schneirov, Shelton Stromquist, and Nick Salvatore, eds., The Pullman Strike and the Crisis of the 1890s: Essays on Labor and Politics (Urbana and Chicago, 1999), 179-203; and Bruce Laurie, Artisans into Workers: Labor in Nineteenth-Century America (New York, 1989). On industrial democracy, see Joseph A. McCartin, Labor's Great War: The Struggle for Industrial Democracy and the Origins of Modern American Labor Relations, 1912-1921 (Chapel Hill, NC, 1997).

6. Two recently edited collections provide an excellent foundation for the study of labor during the Cold War with an emphasis on local labor politics: see Shelton Stromquist, ed., Labor's Cold War: Local Politics in a Global Context (Urbana and Chicago, 2008); and Robert W. Cherny, William Issel, and Kieran Walsh Taylor, eds., American Labor and the Cold War: Grassroots Politics and Postwar Political Culture (New Brusnwick, NJ, 2004). 
nists in the union threatened either the "white-male" nature of their union traditions or their sense of American nationalism. ${ }^{7}$

Left-led unions had the capacity to attract a constituency based on their producerist vision of workers' control as well as to alienate those who resisted their left-wing brand of social and political progressivism, especially in regard to racial equality in the workplace. The case of the Quad Cities FE-UE suggests that the conflation of political and social radicalism with producerist radicalism has oversimplified scholarly understanding of American labor radicalism and overshadowed the degree to which a producerist culture remained alive and well into the 1950s.

TO THE UAW, with its 800,000 members, the Quad Cities were a key spot in taking over the smaller FE constituency of 50,000. The Quad Cities lie 175 miles west of Chicago and span the IowaIllinois border. Along with Chicago, the Quad Cities contained one of the largest concentrations of farm equipment manufacturing in the country, with approximately 10,000 FE members in each. ${ }^{8}$ After their formation in the late 1930s and early 1940s, the 11 FE locals in the Quad Cities established a reputation both within their own union and in the industry at large for their militancy, as evidenced by their high number of shop floor actions in the immediate postwar period. As the largest industrial employer in the Quad Cities, the International Harvester Company and its Farmall subdivision in Rock Island and East Moline were home to the largest FE locals, although John Deere and Company and several other smaller farm equipment firms, such as French and Hecht and Herman Nelson Corporation, employed more than a third of the Quad Cities FE membership.

7. Gerald Zahavi, "Passionate Commitments: Race, Sex, and Communism at Schenectady General Electric, 1932-1954," Journal of American History 83 (1996), 539-44.

8. Ibid. After World War II, the Quad Cities consisted of Davenport, Iowa, and Rock Island, Moline, and East Moline, Illinois. There are really five cities in the area; Bettendorf, Iowa, is often included over East Moline as a member of the Quad Cities. William Roba, The River and the Prairie: A History of the Quad-Cities, 1812-1960 (Quad Cities, 1986), 121. Most of the large FE-UE locals operated in plants on the Illinois side, but members resided on both sides of the border. The UAW membership figures listed above are approximate totals for 1948. See Martin Halpern, UAW Politics in the Cold War Era (Albany, NY, 1988), 3. 
The UAW began its raiding offensive against the Quad Cities FE locals on the morning of February 11, 1949. With the FE contracts expiring, the UAW hoped to gain enough support among FE members to force new elections for union representation before collective bargaining began. This particular raiding effort was a top priority for the UAW. Coming two months after the FE's final rejection of a CIO ultimatum to dissolve and join the UAW, the raid marked the beginning of what would be a turbulent year for the $\mathrm{CIO}$ - a year that ended with the expulsion of 11 "Communist-dominated" unions, including the FE. Lending authority and publicity to the raid was UAW vice-president Jack Livingston, who led the 50 UAW handbill distributors outside the gates of the East Moline Harvester plant. ${ }^{9}$

Foreshadowing the next five years of conflict between the two unions, the handbilling erupted into a violent riot that raged for 30 minutes. Even with the aid of 30 local UAW members from a nearby John Deere Plant, the UAW side was badly outnumbered by roughly $300 \mathrm{FE}$ members. By the time police arrived, scores were injured and 13 men, most aligned with the UAW, were taken to the hospital with serious injuries. The origins of the riot, as reported, are cloudy; each side blamed the other for provoking the violence. What is clear, however, is that both the UAW organizers and the FE members coming off their shift came prepared for conflict with clubs, brass knuckles, padded coats, and even steel helmets. ${ }^{10}$

In the aftermath of the riot, UAW regional director Pat Greathouse, who would administer the Quad Cities locals if they left the FE, justified the raid on the grounds of Communist domination of the FE. He vowed not to relent "until the iron curtain that FE officials have dropped around their members is lifted." The president of FE Local 104 at Harvester, Arvid Sheets, countered that "the UAW has destroyed their organized locals in the Allis-Chalmers and J. I. Case farm equipment plants through misleadership." Workers, he asserted, "cannot afford to be used as pawns in the political game of UAW top officials." ${ }^{11}$

9. Moline Daily Dispatch, 2/10/1949.

10. Rock Falls Record, 2/11/1949.

11. Moline Daily Dispatch, 2/10/1949; Chicago Daily Times, 2/11/1949. 
Sheets's mention of the UAW's "misleadership" of its AllisChalmers local is instructive for understanding the UAW's anti-Communist postwar turn and its subsequent drive to take over FE-UE locals in the Quad Cities. UAW Local 248 at AllisChalmers's West Allis, Wisconsin, plant had a reputation for labor militancy. Rank-and-file support for the local's militant leadership had been especially apparent three years earlier. On April 29, 1946, its members voted 8,091 to 251 to strike the giant farm implement manufacturer. At the center of the strike was the local's insistence on retaining wartime gains that translated into workers' control on the shop floor. ${ }^{12}$

Allis-Chalmers's management held fast to its antiunion tradition, bitterly fighting and beating the strike. The company's antiunion swagger had accrued over the years. Unlike the Big Three auto manufacturers in the late 1930s, the farm implement industry had never been humbled by major union victories. Infighting within the national UAW exacerbated the local's disadvantages, emboldened management's resolve to wait out the strikers, and contributed to the strike's failure. ${ }^{13}$

The loss of the Allis-Chalmers strike helped end the infighting in the UAW between supporters of the newly elected union president, Walter Reuther, and the Thomas-Addes-Leonard coalition (TAL). Reuther supporters generally accommodated Cold War priorities, including anti-Communism, and championed a brand of business unionism that valued cooperation over conflict with employers while securing union goals through labor statesmanship among leaders of labor, business, and government. TAL supporters were a more mixed bag ideologically, ranging from progressive New Dealers to Communists. They held the coalition together with an affinity for the early organizational strategies of the CIO unions that, like the FE, stressed the primacy of the union's economic purpose and understood red-baiting to be a strategy to divide and weaken the labor movement. ${ }^{14}$

12. Meyer, "Stalin over Wisconsin," 158-59; Halpern, UAW Politics in the Cold War Era, 173-75.

13. Goode, Infighting in the UAW, 94; Halpern, UAW Politics in the Cold War Era, 174.

14. Halpern, UAW Politics in the Cold War Era, 128. 


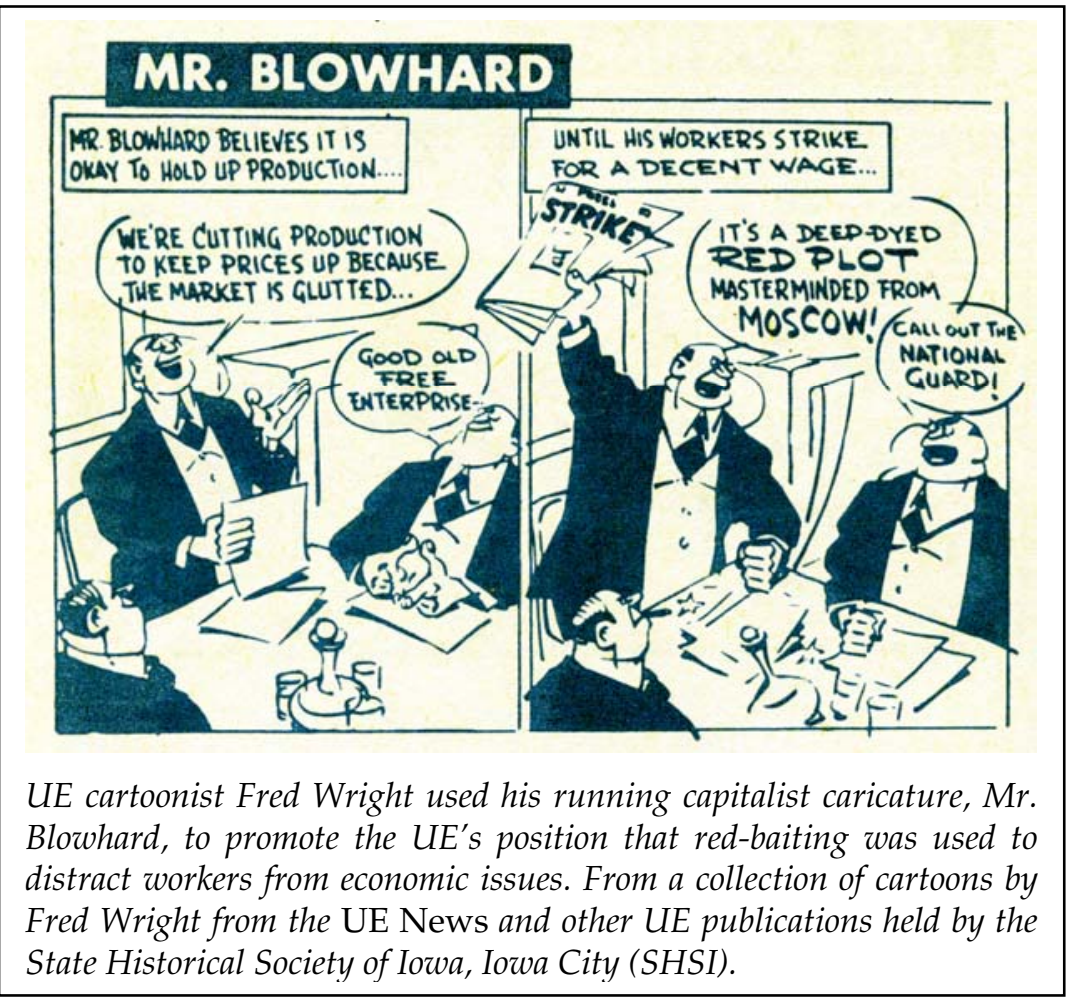

Walter Reuther's anti-Communist position gained traction with the failure of the left-led Allis-Chalmers strike. It was further strengthened several months after the strike's end in March 1947 with the passage of the Taft-Hartley Act, legislation that Allis-Chalmers officials had played an important role in developing. ${ }^{15}$ The Taft-Hartley Act was a blow against all of organized labor, as it limited tactics such as wildcat strikes that had been used successfully to build the CIO. The law also outlawed secondary boycotts, ended the closed union shop, and allowed states to pass right-to-work legislation.

The Taft-Hartley Act hit left-led unions especially hard because it required elected union leaders to sign affidavits affirming that they were not members of the Communist Party or risk decertification by the National Labor Relations Board (NLRB).

15. Ibid., 174. 
Left-led unions in the $\mathrm{CIO}$, such as the FE and the UE, initially stood by their constitutions, which prohibited discrimination based on political affiliation, so they ignored the affidavits until the end of 1949. The UAW, on the other hand, quickly complied with the law in 1947. Reuther was by no means in favor of TaftHartley, but the non-Communist affidavit requirement worked to his advantage by discrediting his left-wing opponents. As far as Reuther was concerned, few unions were more Communistdominated than the UAW's jurisdictional rival, the FE. ${ }^{16}$

The FE rank-and-file's resistance to postwar UAW raids had roots in the loyalty established when the FE became the first to force Harvester into signing a union contract. After the failure of Harvester's company unions following World War I, workers in Harvester's Chicago Tractor Works had enlisted the help of the short-lived Communist Party industrial union, the Trade Union Unity League (TUUL). In 1938 those workers used the protection of the recently passed Wagner Act to win the first ever NLRB election at International Harvester. ${ }^{17}$ The FE came into existence officially as an affiliate of the nascent Steel Workers' Organizing Committee (FESWOC), a growing force in the new CIO.

The union's foothold in Harvester's Chicago Tractor Works provided a base of operations that would successfully extend the FESWOC to other Harvester plants, including those in the Quad Cities. By the end of World War II, the FESWOC would capitalize on assistance from the National War Labor Board to gain certification, a general wage increase, a strengthened grievance procedure, and a maintenance-of-membership clause. ${ }^{18}$ Those gains helped the union attract members and win its own international CIO charter in 1942, when it became the United Farm Equipment and Metal Workers of America (FE).

The new charter did not sit well with the UAW, which saw farm equipment workers as a natural growth sector, given the

16. Ibid., 205.

17. Ibid., 77-82, 85.

18. Gary M. Fink, ed., Labor Unions (Westport, CT, 1977), 90; Robert Ozanne, A Century of Labor-Management Relations at McCormick and International Harvester (Madison, WI, 1967), 200-208; Toni Gilpin, "Left by Themselves: A History of the United Farm Equipment and Metal Workers Union, 1938-1955" (Ph.D. diss., Yale University, 1992), 88-106. 
similarities between automobile and farm machinery production. By 1937, the UAW had achieved considerable success in the farm equipment industry, mainly in Allis-Chalmers, J. I. Case, and International Harvester truck plants. ${ }^{19}$ The $\mathrm{CIO}$, along with the FE and the UAW, sought a merger that would unite the workers in the farm equipment industry, but several botched attempts revealed irreconcilable visions of trade unionism. ${ }^{20}$ With hopes of a peaceful merger gone, the Reuther-led UAW sought to incorporate the FE on a local-by-local basis through aggressive raiding.

Prospects looked good for the UAW. In 1948 the UAW won a controversial election at the FE's largest local at the Caterpillar Tractor plant in Peoria, Illinois, whose 16,000 workers represented 25 percent of the FE's membership. In addition, Pat Greathouse was well on the way to rebuilding the formerly militant AllisChalmers Local 248 in Reuther's image. ${ }^{21}$ But when Greathouse directed his attention to the FE in the Quad Cities in 1949, he got a taste of the bitter opposition the UAW would encounter over the next six years. After the February 11 riot, Ed Neilson, president of FE Local 111, seemed to challenge the UAW to engage in more raids in the Quad Cities: "We're going to protect our rights," he asserted. "And if we affiliate with the UAW, we'll do it at our convention in a democratic manner. We will not be forced or strong-armed into doing anything!" ${ }^{22}$

\section{Meyer, "Stalin over Wisconsin," 64-68.}

20. For more on the complex politics surrounding the proposed merger, see the conflicting analyses in Goode, Infighting in the UAW, 103; and Gilpin, "Left by Themselves," 229-33.

21. Preferring to deal with the UAW, Caterpillar was able to arrange an early NLRB election in which the FE would not be allowed to participate due to local leaders' refusal to sign non-Communist affidavits. FE supporters pursued the awkward and difficult position of urging their fellow workers to vote "no union" and continuing as a noncertified but popularly endorsed union. The FE lost by a two-to-one margin to the UAW, compelling the FE's leadership to conduct an immediate referendum with the membership over the affidavit issue in June 1948. In what would be the first of many pragmatic compromises made by FE members during the Cold War, the referendum passed by a substantial majority, making the FE the first left-led union to abide by the nonCommunist affidavits. See Goode, Infighting in the UAW, 105; and Gilpin, "Left by Themselves," 204-14.

22. Rock Falls Record, 2/11/1949. 
THE FE did affiliate on its own democratic terms with another union, though not with the UAW. Following the failed merger with the UAW in 1947, the CIO executive board gave the FE an ultimatum: merge with the UAW or have its charter formally withdrawn. Considering expulsion imminent, the FE executive board began merger discussions with the UE in the months leading up to the $1949 \mathrm{CIO}$ convention.

By 1949, the UE and the FE had a great deal in common. Formally welcomed into the CIO in 1936, the UE represented industrial workers in the burgeoning radio and electrical sectors. In 1937 the UE took a turn to the left when it welcomed 15,000 workers allied with James J. Matles's Communistdominated Federation of Metal and Allied Unions. The UE's leftist leadership guided the union's dramatic membership growth throughout the 1940s. Like the FE, the UE fell victim to intra-CIO raids throughout the 1940s as the CIO's leadership solidified its anti-Communist position. Frustrated with raids, the UE requested a no-raiding agreement from the $\mathrm{CIO}$, which was refused. In turn, the UE ceased paying dues to the $\mathrm{CIO}$ and was expelled during the 1949 convention, which declared that the CIO would "no longer tolerate within the family of the CIO the Communist Party masquerading as a labor union." ${ }^{23}$

The UE, with more than 400,000 members, allowed for generous merger terms, as the boost in membership would be needed in what were certain to be a stormy next few years. ${ }^{24}$ The FE was allowed to maintain its organizational infrastructure, officers, and constitution and an autonomous Farm Equipment Council that would control contract negotiations in the farm equipment locals. FE locals were even allowed to maintain their former local numbers and name: FE-UE. With strong endorsement from the FE leadership, the membership approved the merger, with 84 percent voting in favor. One resolution on the merger, passed by FE Local 822 in the Quad Cities, praised

23. Fink, Labor Unions, 79-83. Two fine histories of the UE cover the UE's rise and fall in considerable depth: Ronald L. Filippelli and Mark McColloch, Cold War in the Working Class: The Rise and Decline of the United Electrical Workers (Albany, NY, 1995); and Ronald W. Schatz, The Electrical Workers: A History of Labor at General Electric and Westinghouse, 1923-1960 (Urbana and Chicago, 1983).

24. Gilpin, "Left by Themselves," 245-46. 
the UE's commitment to "democratic, rank and file unionism" but acknowledged that the merger was not ideal as it failed to unite the workers in the industry. ${ }^{25}$

The UE was confident in its independence, but understood that preserving its core ideals conflicted with the goal of achieving labor unity. In fact, the UE took important steps after expulsion to resist isolation from an increasingly hostile CIO. To the ire of several expelled left-led unions hoping to create a powerful "third labor federation," the UE, the largest expelled union, was not interested and put a halt to the project. At the 1950 UE national convention, a labor unity resolution opposed such a course, suggesting that "the proponents of such a move demonstrate a lack of confidence that rank and file resistance to the sell-out leadership of the CIO and AFL unions can be successfully developed within these unions." ${ }^{26}$

Such optimism about the potential resistance of the CIO rank-and-file, however, did not reflect the gravity of UE's situation. Although the addition of roughly 50,000 FE members gave the UE nearly a half-million dues-paying members in 1950, its numbers were fluid and declining. The newly CIO-chartered jurisdictional rival to the UE, the anti-Communist International Union of Electrical, Radio and Machine Workers (IUE), achieved initial success in some of the largest UE East Coast locals of Westinghouse and General Electric. By 1953, CIO union raids and substantial industry layoffs had whittled the combined UEFE membership down to $203,000 .^{27}$

The labor unity resolution, which was drafted anew every year at both national and district conventions, would prove an important and controversial forum for the future disaffiliation of the FE-UE Quad Cities locals in UE District 8. Significantly, the labor unity resolution at the 1950 national convention pro-

25. Ibid., 246-47; "Resolution on UE-FE Merger," December 1949, UE District Council Eight Records, 1938-1955 (hereafter cited as UE8 Records), Iowa Labor Collection, State Historical Society of Iowa, Iowa City.

26. "Labor Unity," ca. 1950, UE8 Records. For more on the interest in creating such a left-led "third labor federation," see Judith Stepan-Norris and Maurice Zeitlin, Left Out: Reds and America's Industrial Unions (New York, 2003), esp. 297-327.

27. Schatz, The Electrical Workers, 232. 


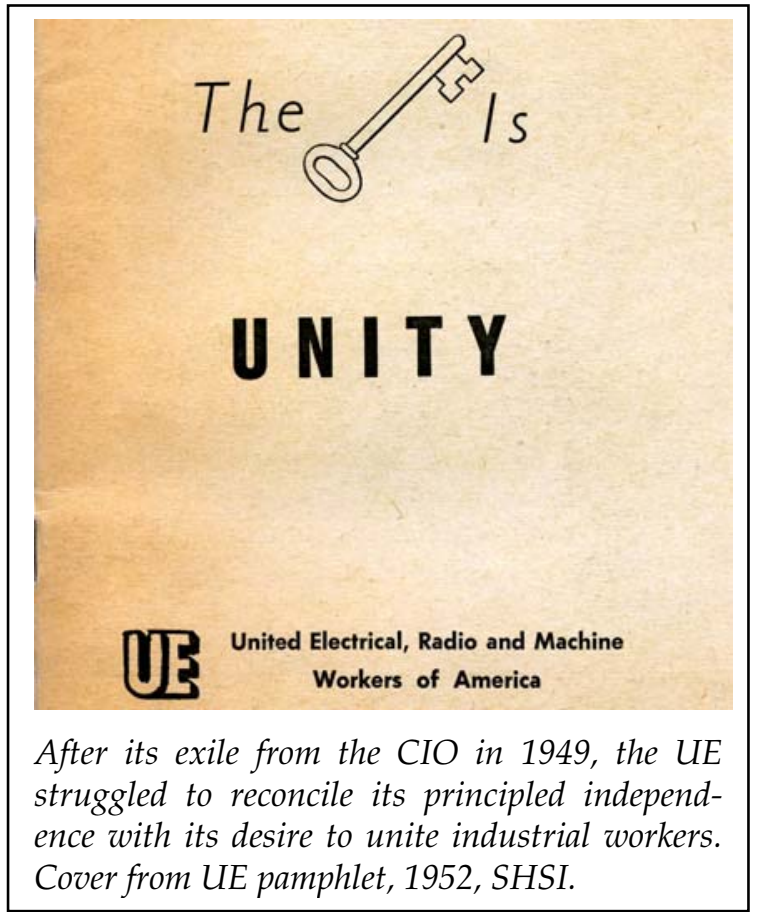

posed an ambiguous definition for "labor unity." Stating that a "sound program for labor unity" was necessary for the UE to survive, the resolution failed to outline such a program or hint at what might be sacrificed to achieve such unity if push came to shove - something that the local delegates of UE District 8 would point out repeatedly after five years of waiting in vain for such a program. ${ }^{28}$

AFTER LEAVING THE CIO, the FE proved more successful in maintaining its locals than did its UE counterparts. No UAW raids on old FE locals between 1949 and 1953 were successful; the FE-UE was able to retain all of its Quad Cities locals over those four years. In the months leading up to the renegotiation of the FE-UE's contract with International Harvester in 1952, the

28. "Labor Unity." 
union retained many key contract provisions won in 1941 and maintained them by striking every contract year except $1949 .{ }^{29}$

To retain membership against UAW raids, the FE-UE emphasized its contractual advantages. The FE-UE literature highlighted advantages in paid holidays, overtime, vacations, night bonuses, and clauses that protected plantwide seniority with broad job classifications, but the core of the FE-UE's appeal was its strong grievance and steward system. An FE-UE contract barred foremen from the first step of a grievance, allowed for a union steward for every shift in each department, gave discharged and suspended employees access to the grievance procedure, and, perhaps most important, let the stewards handle grievances on company time. In comparable UAW contracts, the number of stewards was limited to ten per plant, workers were required to initiate their own grievances, discharged and suspended employees had no grievance recourse, and stewards had to handle grievances on their own time outside of work. ${ }^{30}$

The strong grievance and steward system was the backbone of the FE-UE and was pivotal in organizing shop-floor actions. One aspect of the FE-UE contract that management considered a constant nuisance was the right of workers to walk out during the span of a contract when the grievance procedure had been exhausted. That clause allowed FE workers to maintain their militant tradition of work stoppages without the threat of a debilitating lawsuit against the national union. The FE's active steward system translated into more grievances, increasing the potential number of unresolved grievances that might lead to union action. Such militancy did not always translate into success, and could even exacerbate workplace disputes, but left-led unions considered the rewards worth the risk. ${ }^{31}$

Such an attitude of workers' control was exactly what the UAW was working to stamp out of the CIO. With Walter Reuther's ascension, the UAW agreed to help the company curtail

29. James E. Foley, "Labor Union Jurisdictional Disputes in the Quad-Cities' Farm Equipment Industry, 1949-1955" (M.A. thesis, University of Iowa, 1965), 30-35; Ozanne, A Century of Labor-Management Relationsr, 217, 208.

30. "Comparison between Farm Equipment-UE Contracts in Harvester and UAW Contracts in J. I. Case, April 10, 1952," UE8 Records.

31. Gilpin, "Left by Themselves," 295-97. 
unauthorized work stoppages and discipline members in exchange for contract concessions as well as assurances that the national union would not be sued under the Taft-Hartley Act for any illegal walkouts. The UAW leadership failed to control all desired work stoppages among its members, but when compared to its FE counterparts, fundamental differences are clear. From 1945 through 1951, the UAW and FE represented approximately the same number of workers at International Harvester, with the UAW locals doing similar work in Harvester truck plants. During that period, the FE locals organized 849 work stoppages to the UAW's $171 .^{32}$

The FE's aggressive use of work stoppages on the shop floor framed how the union approached bargaining and contracts. FE contracts, like those of other militant unions, were not long-term; they tended to be short and basic. Workers preferred such contractual ambiguity because it allowed them more latitude in defining what historian Steven Meyer calls the "workplace rule of law." John Boynton, from one of the larger FE locals at Harvester in East Moline, recalled, "We had a little contract. It said what it meant, and it meant what it said." Several FE locals around the country even operated without any contract. In the event of a workplace dispute, FE-UE leader Don Harris explained, "We were in favor of job action in order to get something done." ${ }^{33}$

Workers took notice of the substantive differences between the contracts. Lawrence "Newt" Hoskinson of Local 104, who left the FE-UE because of its connection to the Communist Party and supported UAW raids, admitted that "our [FE] contract had always compared better than any UAW contract I ever seen... . I wish I had an old contract. ${ }^{34}$ It is important to acknowledge, though, that many workers were attracted to Reuther's promise

32. Ibid., 297-300.

33. Meyer, "Stalin over Wisconsin," 104; John Boynton, interview by Gregory Zieren, Quad Cities, 7/29/1980, Iowa Labor History Oral Project (hereafter cited as ILHOP), State Historical Society of Iowa, Iowa City; Shelton Stromquist, Solidarity and Survival: An Oral History of Iowa Labor in the Twentieth Century (Iowa City, 1993), 173. For an overview of UE contracts in District 8, see Rosemary Feurer, Radical Unionism in the Midwest, 1900-1950 (Urbana and Chicago, 2007), 235.

34. Lawrence "Newt" Hoskinson, interview by Gregory Zieren, Quad Cities, 7/9/1980, ILHOP. 


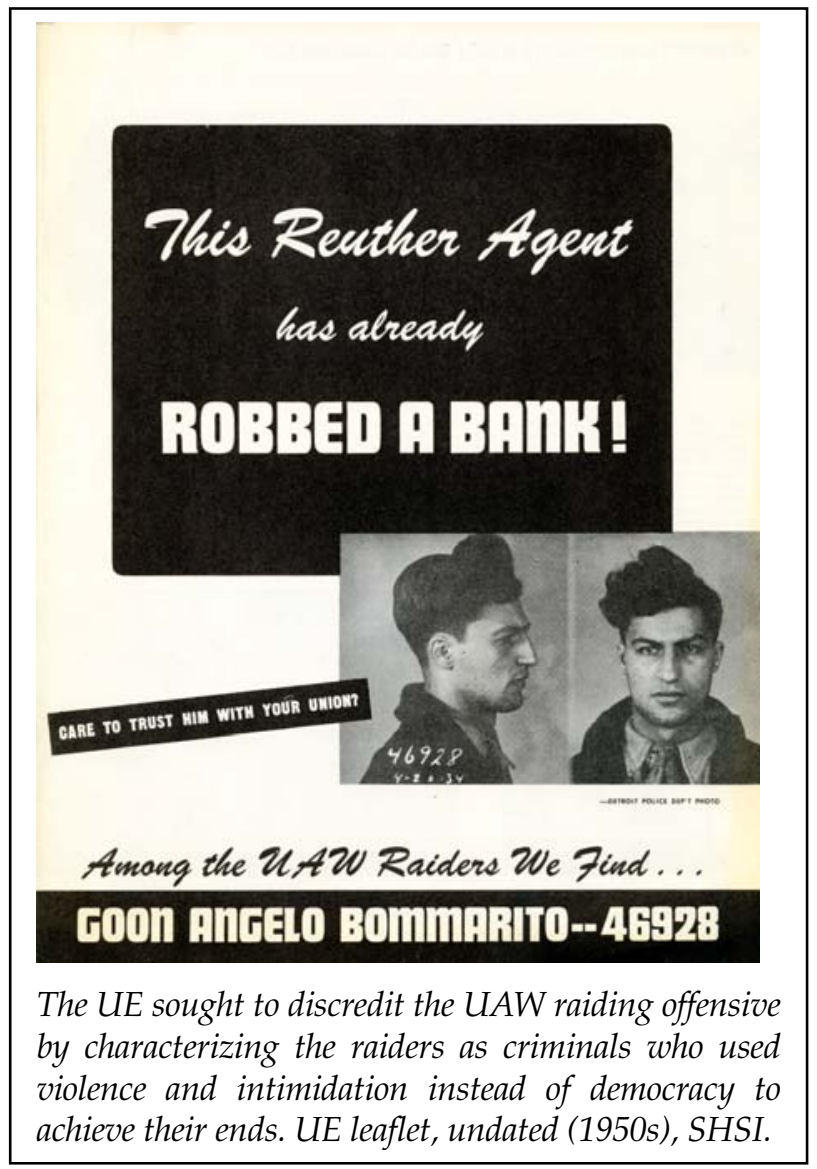

that labor would enjoy a bigger share of the pie as the pie grew larger through uninterrupted production and growth, and many believed that Reuther's long-term contracts would ensure stability and benefit them more financially in the long term. However, the failure of UAW raids and the barrage of work stoppages suggest that a commitment to militant unionism and FE-UE contracts prevailed. This edge in contracts, however, diminished after the union struck International Harvester in 1952.

Both the FE-UE and Harvester came to the bargaining table in 1952 with ambitious agendas. While the FE-UE sought to strengthen its shop floor presence by eliminating no-strike and slowdown language and increasing the number of stewards, 
Harvester management chose 1952 as the year to eliminate once and for all "the worst contract in Harvester history." The difference between FE-UE and UAW contracts was highlighted during negotiations, as Harvester management openly aimed to settle on terms akin to its UAW contracts. ${ }^{35}$

The inevitable strike began on August 21, and involved some 23,000 FE members at Harvester plants across the country. Anticipating the strike, Harvester management instantly offered incentives to get replacement workers and succeeded in reopening its plants. The company's back-to-work plan also exploited racial divisions among workers, which sparked minor violence in Chicago. That, in turn, persuaded the courts to issue a devastating injunction that drastically diminished the picket lines. ${ }^{36}$

As the Red Scare and McCarthyism escalated, the mainstream press in Iowa and Illinois also helped the company's cause by highlighting questions surrounding Communism and the FE-UE. The FE strike was undoubtedly damaged by heavy press coverage of a Chicago-based House Un-American Activities Subcommittee investigation looking into Communism in industry. On September 14, four weeks into the strike, the Des Moines Register, Iowa's most widely distributed daily, ran a front-page story on the recent testimony of two FE men out of the Quad Cities, Donald O. Spencer and Walter Rumsey, who testified to their own activities in the Communist Party and named as Communists several prominent FE leaders, who were at the time conducting the strike. ${ }^{37}$ Three days later, District 8 regional director and open Communist William Sentner was arrested in the Quad Cities on charges of conspiring to overthrow the U.S. government by force. Sentner's arrest, in particular, would fill the pages of local newspapers and UAW handbills in the time leading up to his guilty verdict in $1954 .^{38}$

On November 16, after 87 difficult days out, and with roughly 8,000 strikers already back on the job, all Harvester plants operational, and no favorable resolution in sight, FE

35. Gilpin, "Left by Themselves," 389-90.

36. Ibid., 400-408.

37. Des Moines Register, 9/14/1952.

38. Foley, "Labor Union Jurisdictional Dispute," 41-46. For an in-depth analysis of Sentner, see Feurer, Radical Unionism in the Midwest. 


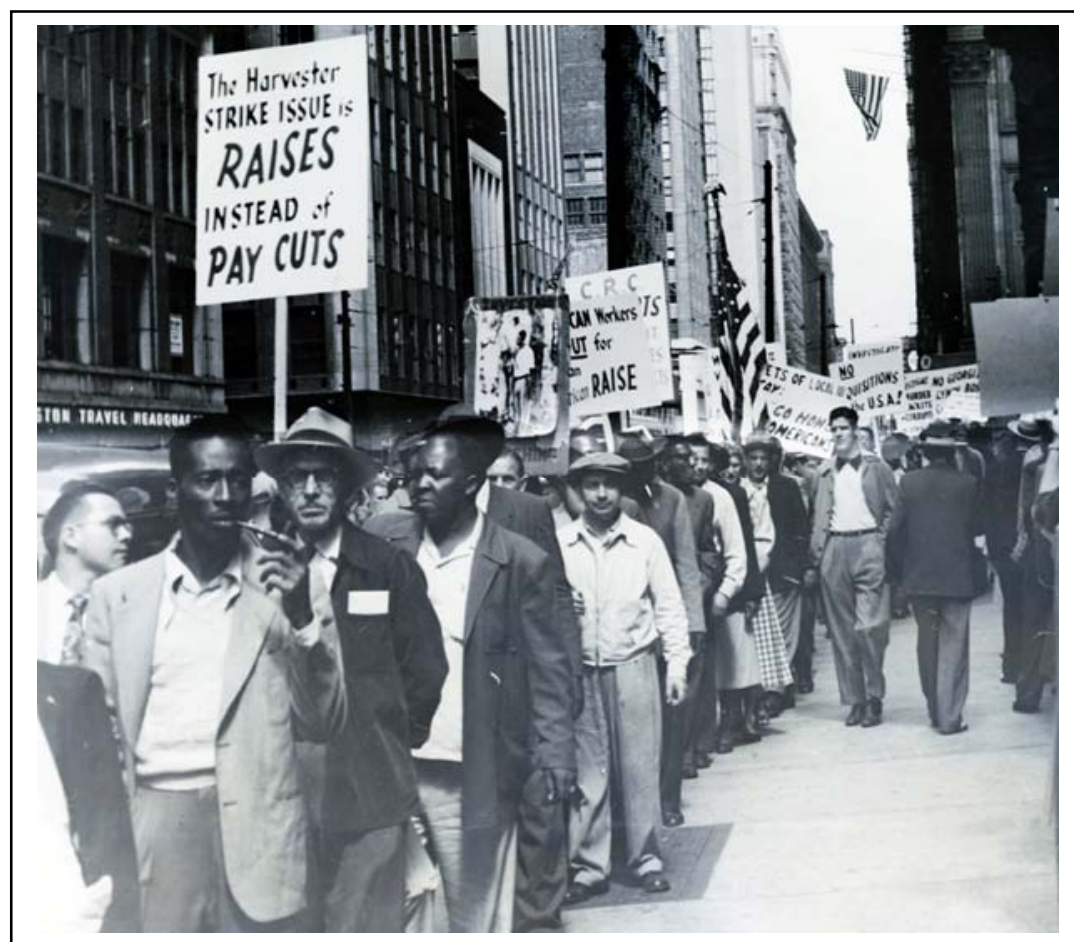

A massive picket line from the Harvester strike parades through a downtown area in the Quad Cities in 1952. Photo from SHSI.

leaders called off the strike. Harvester management presented FE negotiators with a "take-it-or-leave-it" offer, and UE president James Matles and former FE president Gerald Fielde signed it. In a letter informing the locals of the settlement, Fielde announced that the union had settled a three-year contract "on terms substantially the same as in the UAW-CIO Contract." ${ }^{39}$ With this inferior contract signed and subsequently approved by a beleaguered constituency six months later, the FE-UE contract lost its uniquely militant structure, rooted in an active steward and grievance system, and with it one of its strongest competitive edges against UAW raids.

39. James J. Matles to UE International Representatives and Field Organizers, 11/17/1952, and "Statement sent by Gerald Fielde, Chairman, Harvester Conference Board to the Locals, November 17, 1952," UE8 Records. 
CONSIDERING THE STRIKE'S DEVASTATION and the poor contract, the ensuing loyalty of farm equipment workers at Harvester to the FE-UE surprised the UAW. As 1952 was a bargaining year, and thus an opportune time for union raids, the UAW sought to capitalize on discontent from the strike by gathering the requisite number of signatures to petition elections in three of the largest FE-UE locals. The first two elections, conducted in Chicago and Indiana in April 1953, resulted in decisive FE-UE victories. No doubt based on those results, the UAW withdrew from the election at East Moline one week before the election. ${ }^{40}$

Yet all was not well with the FE-UE in the Quad Cities. The FE-UE easily won the uncontested 1953 election in East Moline with 2,163 votes, but 1,302 workers were dissatisfied enough with the FE-UE to vote the only other option, "no union." ${ }^{41}$ That substantial vote of no confidence in the FE-UE was the result of a concerted effort by an organized group of pro-UAW workers inside the plant calling itself the Employees Cooperative Association (ECA). To the initial disbelief and sustained ire of FE-UE loyalists and UE national officers, the man leading the charge against the FE-UE was one of the most militant, active, and popular leaders in the FE-UE, John Watkins.

Watkins's controversial decision to embrace a former foe Reuther's UAW - illustrates how some union leaders came to view mainstream unionism as the only option available at the time to preserve FE's tradition of labor militancy in the Quad Cites. Starting out as a machine operator in Harvester's East Moline Works, Watkins became an early leader in the union and in 1938 was one of the nine FE leaders to sign the certificate of affiliation with the CIO. Through the years of strikes and tough negotiations, Watkins's temper and intransigence earned him a reputation among the Harvester labor relations staff as one of "the two livest wires in FE-CIO" (the other was Gerald Fielde). At the time of the 1952 strike and his dismissal from the FE-UE, Watkins was serving as an FE-UE international representative and the de facto leader of the FE in the Quad Cities. ${ }^{42}$

40. Gilpin, "Left by Themselves," 411-12; Foley, "Labor Union Jurisdictional Dispute," 49-50.

41. Foley, "Labor Union Jurisdictional Dispute," 51.

42. Gilpin, "Left by Themselves," 578-80, 583. 


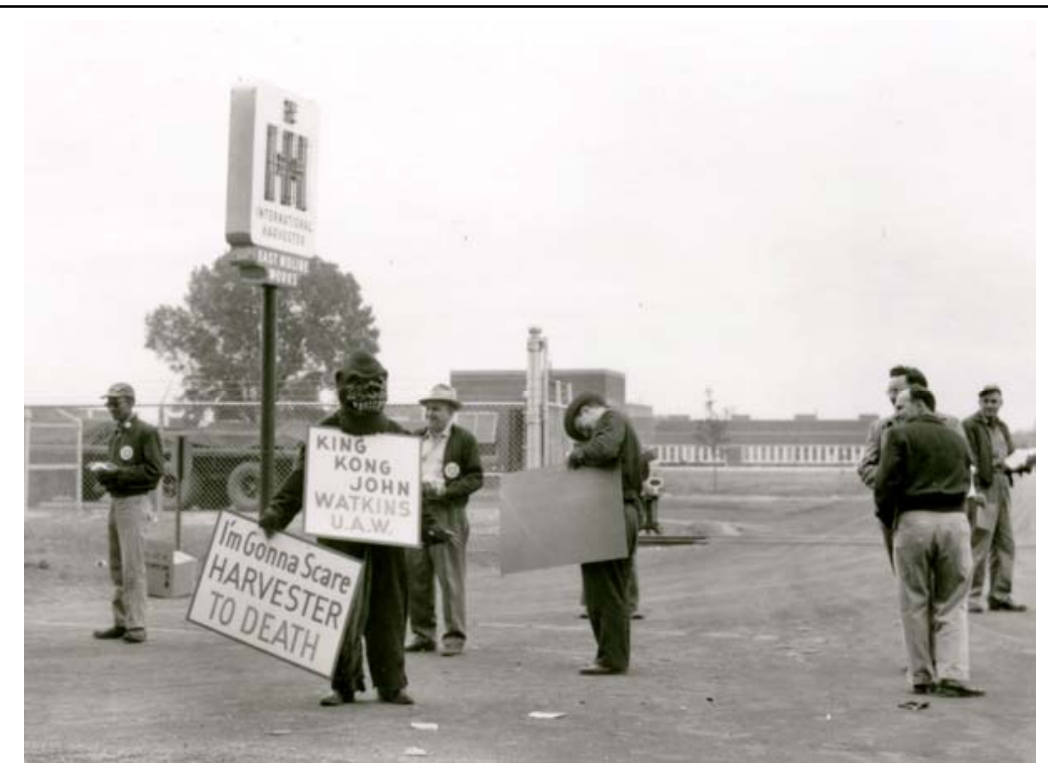

This man, who followed John Watkins's lead into the UAW at the end of the International Harvester Strike in 1952, displays some picket line theatrics for passing motorists. Photo from SHSI.

Fiercely loyal to the interests of the FE in the Quad Cities above all else, Watkins approached the merger with the UE cautiously from the beginning. The FE and the UE shared historic ties to the Communist Party, but it is clear that although the FE locals in the Quad Cities were a bulwark of labor militancy, they were never a haven for the kind of political or social radicalism championed by the UE and many FE leaders. Watkins was quite progressive on such matters, but he understood his constituency and tried to represent their interests, which caused friction between the two unions. ${ }^{43}$

The left-wing stances on domestic and foreign policy issues that the UE commonly took could spur internal dissent. At the

43. At the hearing during the 1952 Harvester strike, Donald O. Spencer and Walter Rumsey and others had identified Watkins as a Communist. When called before the House Committee on Un-American Activities himself in April 1954, Watkins denied ever being a member of the $\mathrm{CP}$ and refused to name others who might be; he did note, however, that prior to 1948, he had cooperated with the CP and been involved with party activities. Gilpin, "Left by Themselves," 579-80. 
UE's 1950 national convention, for example, a foreign policy resolution was introduced that strongly condemned the Marshall Plan as a tool of Big Business. The resolution also encouraged increased cooperation with Russia "to find a peaceful solution to all differences and to discuss the terrors of atomic weapons and to take action to avoid their use. ${ }^{\prime 44}$ The large FE-UE Local 104 at Harvester's East Moline Works was one of the few delegations to vote unanimously against the resolution. The one familiar UE leader working in the Quad Cities who was open about his Communism, District Representative William Sentner, generally kept his Communist politics out of the union's everyday business. In fact, many active FE-UE members in the Quad Cities who knew Sentner refused to believe that he was a Communist. ${ }^{45}$

After the strike, Watkins began to see the UE's continued emphasis on radical politics as a dangerous abstraction that distracted from local union business. As a key FE leader in the Quad Cities, Watkins worked extensively with UE District 8 director Don Harris after the 1949 merger. The two did not get along, which interfered with a smooth transition for the merger. Watkins felt that the UE, through Harris, aimed to improperly influence the Quad Cities locals on political matters. After his expulsion from the UE in 1953, Watkins claimed that "in 1950 Don Harris . . . began with the UE campaign to take over FE locals." He added, "The issue has been and remains UE dictatorial control of FE locals for selfish political purposes." Watkins also complained that UE Director of Organization James Matles criticized him for not carrying on "the proper political work within the local union." ${ }^{46}$

The Quad Cities FE locals also lagged behind their progressive counterparts in regard to civil rights in the workplace and union. Most unions in the $\mathrm{CIO}$ championed civil rights, but left-

44. United Electrical, Radio and Machine Workers of America, 15th Convention Proceedings, 1950 (New York, 1950), 169.

45. See, for example, James Parmley, interview by Gregory Zieren, Quad Cities, $5 / 3 / 1980$, ILHOP. UE field staffers in other parts of the country were not so apolitical. See, for example, David Montgomery's experiences with the UE in New York City during the 1950s, described in James Barrett, "Class Act: An Interview with David Montgomery," Labor: Studies in Working-Class History of the America 1 (2004), 30-31.

46. Labor's Daily, 8/6/1953; Foley, “Labor Union Jurisdictional Dispute," 55. 
led unions were especially active in this regard. Unlike FE locals in Chicago, the Quad Cities locals had no African Americans in leadership positions as late as $1953 .{ }^{47}$ Following the 1952 annual convention of the National Negro Labor Council, a short-lived project of progressive unions, both black and white members of the FE initiated steps to establish a Quad City Negro Labor Council. The provisional committee, seven of nine of whom were members of the FE-UE, called attention to the fact that "there are few, and in many cases, no Negroes employed in the industrial plants in the Quad Cities." ${ }^{\prime 4}$

The absence of African American workers in the farm equipment industry and in the FE locals reflects the racial segregation prevalent in the Quad Cities at the time. Intent on documenting and combating what many saw as Jim Crow laws operating in the Quad Cities, a small group of progressive Catholic priests, labor organizers, and reformers formed the League for Social Justice. After two years of research and polling locally, the group published Citizen 2nd Class: Negro Segregation and Discrimination in Davenport, 1951. The report documented a "high level of discrimination," which was "strictly, if not officially enforced" in all areas of life. Davenport's 2,500 African Americans (out of the city's total population of 74,594 ) were forced into two dense ghettos with substandard education and were refused most public services. The survey found no African Americans employed as teachers, office workers, or civil servants; and among 18 large firms employing more than 10,000 workers, there were only 175 black workers in the lowest-paying jobs. In the case of the farm implement industry, Harvester was one of the few that employed African Americans, but, as the FE noted in 1954, the firm "maintained a rigid policy of concentrating

47. Roy Best, Letter to Membership, 5/1/1953, UE8 Records. By the end of 1949, Chicago's FE Local 108 at Harvester's McCormick Works had voted in a progressive slate of officers; 4 of 11 members on the executive board, 3 of 7 grievance men, and 45 percent of the steward body were African Americans. Although most of the black stewards came out of the foundry, some came from other departments. Gilpin, "Left by Themselves," 363.

48. "Provisional Committee to Establish Quad City Negro Council," UE8 Records. For a general narrative and statistical overview of African Americans in the industry, see Robert Ozanne, The Negro in the Farm Equipment and Construction Machinery Industries (Philadelphia, 1972). 
them in the main in the foundry and on the lowest paid and dirtiest jobs in the plant." ${ }^{\prime 49}$

Recent scholarship on race and the CIO suggests that the ideal of "nonracial syndicalism" championed by CIO unions was often not realized in workplaces where stratification by race and by wage or skill level coincided. Historian Bruce Nelson notes that for white workers, "genuine equality for blacks, based on their ability and seniority, could impose an economic cost on them; it could mean giving up their privileged access to the skilled jobs, higher pay, and better, safer working environment that the wages of whiteness proffered.. ${ }^{\prime \prime 0}$ Certainly companies played a central role in racially segregating workplaces, but workers and their labor unions played a role as well.

Both the UAW and FE-UE espoused civil rights in the workplace and union, but the UAW was not nearly as aggressive on this front. Historian Robert Zieger has shown that under Walter Reuther's leadership, the UAW fully respected the racial lines keeping black workers from higher-paying skilled positions. Zieger's conclusion is bolstered by Mohammad A. Chaichian's research on race relations in Dubuque - another community up the Mississippi River from the Quad Cities with sizable industry and comparably small percentages of black citizens. In his examination of an old John Deere FE local that joined the UAW in 1947, Chaichian found an astounding lack of both civil rights activism and racial sensitivity; for example, members of the local dressed in blackface for their Christmas party in $1950 .^{51}$

To suggest that there was likely tension between the national UE and the FE-UE locals of the Quad Cities in regard to

49. George William McDaniel, "Catholic Action in Davenport: St. Ambrose and the League for Social Justice," Annals of Iowa 55 (1996), 244-57; "Provisional Committee to Establish Quad City Negro Council"; Bruce White to L. M. Gildea, 9/24/1954, UE8 Records.

50. Bruce Nelson, Divided We Stand: American Workers and the Struggle for Black Equality (Princeton, NJ, 2001), 206; David R. Roediger, Working toward Whiteness: How America's Immigrants Became White: The Strange Journey from Ellis Island to the Suburbs (New York, 2005), 199-224.

51. Zieger, The CIO, 347; Mohammad A. Chaichian, White Racism on the Western Urban Frontier: Dynamics of Race and Class in Dubuque, Iowa (1800-2000) (Trenton, NJ, 2006), 176-81. See also Roediger, Working toward Whiteness, 216; and Lichtenstein, The Most Dangerous Man in Detroit, 206-11, 372-76. 


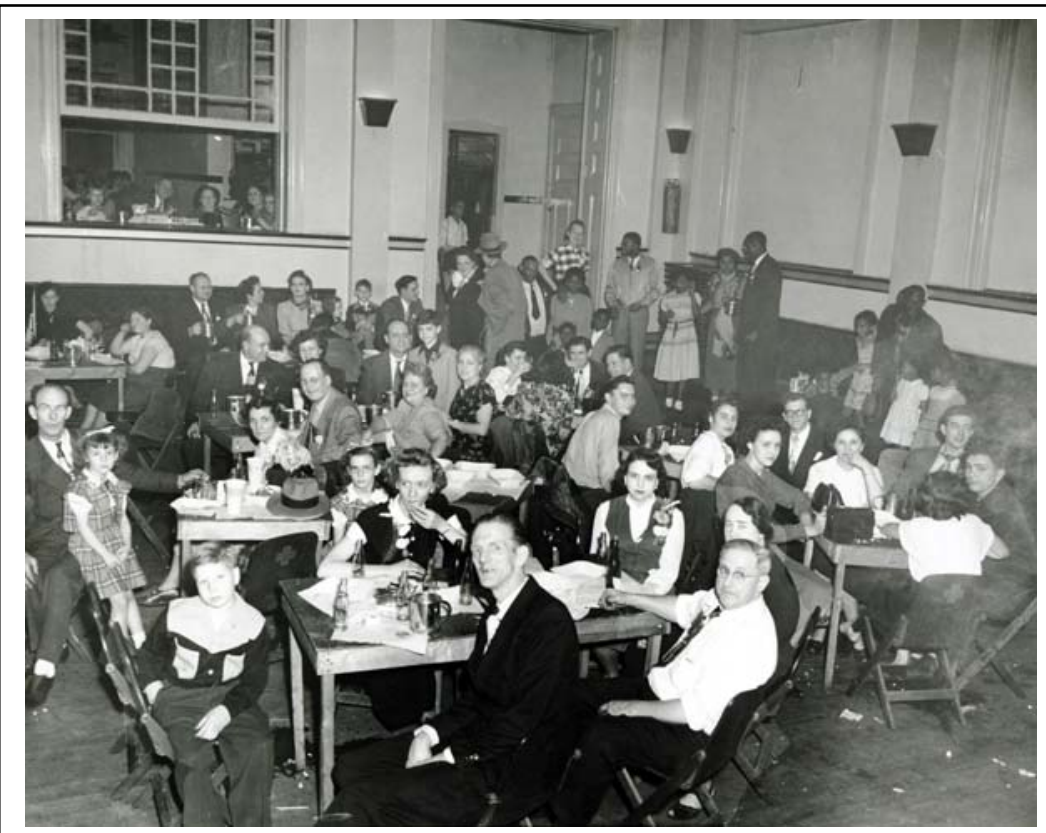

The FE-UE locals in the Quad Cities officially espoused civil rights, although union social gatherings, like this one at Local 810, illustrate the stark reality of racial segregation.

civil rights and foreign policy does not mean that the Quad Cities workers were of one mind or eschewed all aspects of left-led social unionism. ${ }^{52}$ Rather, it serves as a reminder that in the minds of workers, labor militancy did not always come packaged along with a progressive agenda on civil rights or a desire to make peace with the Soviet Union. In this respect, the Quad Cities FE-UE locals resemble Gerald Zahavi's "right-wing Communists" in Schenectady, New York, where, he notes, "In calling for a dramatic escalation of organizing work among blacks and women, interjecting foreign policy issues ... and applying rigorous tests of ideological fealty," the UE "intro-

52. Studies of other socially progressive left-led locals include Lisa Kannenberg, "Putting the 'I' before 'UE': Labor's Cold War in Schenectedy-GE," in Labor's Cold War; and Toni Gilpin's case study of FE Local 236, in Louisville, Kentucky, in "Left by Themselves," 417-568. 
duced additional strains into a local party organization already under siege within the plants and without."

When the UE was a stable independent union offering superior contracts, such incompatibility might not have presented a problem. However, as it became clear that the UE's political radicalism in the Cold War climate would only interfere with trade union business and local solidarity, the FE-UE workers had to continually weigh the benefits of left-led unionism against the immediate and potentially devastating costs.

THE EVENT that broke the fragile alliance between John Watkins and the UE occurred during the 1952 strike. The amount of UE financial and staffing resources allotted to the old FE locals had been a continuous source of friction throughout the merger, but feelings of being shortchanged by the UE national office hit new heights in the midst of the strike. The UE, struggling to keep afloat as an independent union, could not afford to wage the kind of strike many Harvester workers expected. Burton C. Foster, who was involved in the strike, cites the strike as the turning point against the UE; he recalled that "there was very little, if any, financial support given to the farm equipment workers by UE. The farm equipment people felt like they were second-class citizens within UE." ${ }^{54}$

To compound the frustration with the UE, many in the FEUE felt that signing the inferior contract at the end of the strike was not in the best interests of the farm equipment workers. John Watkins, in particular, thought that returning to work without a contract and militantly governing labor relations at Harvester with shop floor actions would be a wiser course than being saddled for three years with an inferior contract. Because such a course would have left all FE-UE locals at Harvester open to immediate UAW raids, many workers concluded that top UE leadership signed the contract in order to retain duespaying members.

53. Zahavi, "Passionate Commitments," 540.

54. Gilpin, "Left by Themselves," 573-76; Burton C. Foster, interview by Paul Kelso, Quad Cities, 1/1/1978, ILHOP.

55. Gilpin, "Left by Themselves," 582. 


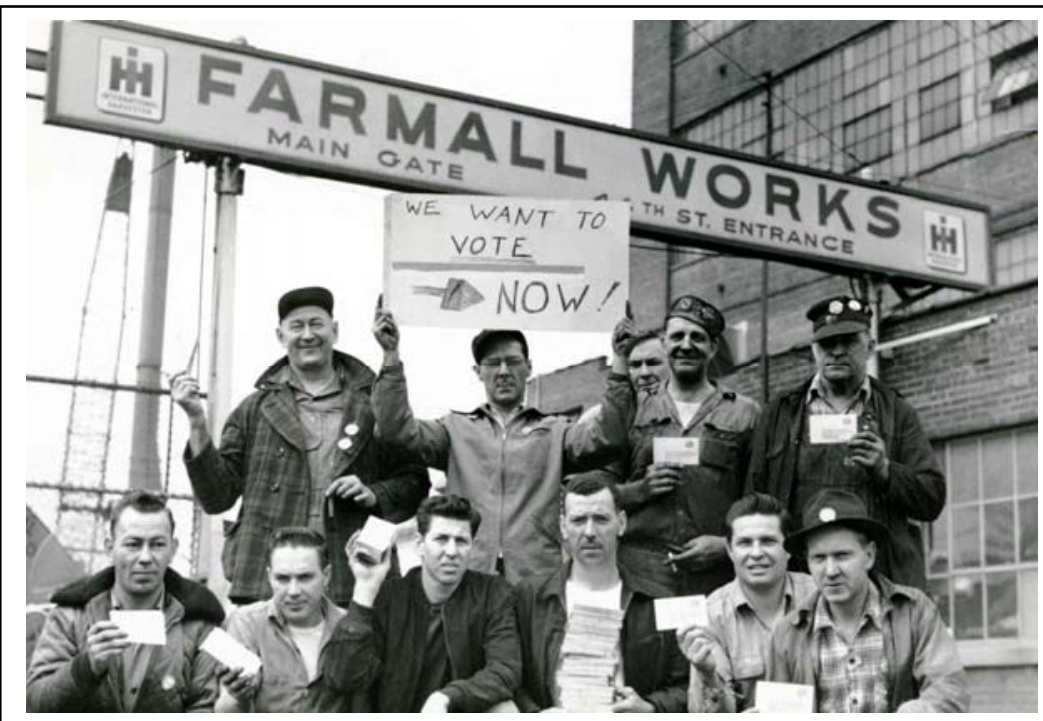

These Farmall workers, members of the Employees Cooperative Association, proudly display signed request cards to be sent to the National Labor Relations Board in hopes of prompting a new election to decertify the FE-UE. Photo from SHSI.

The turbulent month of August 1953 ended in dual unionism in all of the Harvester locals. Early in the month, John Watkins was finally fired from his officer post in the FE-UE because, as James Matles put it, he "continually worked to undermine the policies, program and rules of the International Union.." ${ }^{156}$ Watkins was not the only one pushing for UAW representation while still an officer of the FE-UE, though. In fact, half of the officers of Farmall Works Local 109 in Rock Island were informally working for the UAW, including the local's president. Burton C. Foster of FE Local 104 explained the chaotic dual unionism that spread across the Harvester shop floor:

The union hall remained in possession of the FE people who had moved over to UAW, and the UAW sign went up. Three of the FE people were now on the UAW staff. The company continued to recognize FE, and they had no one to fill stewards' positions or

56. James J. Matles to John Watkins, 8/3/1953, UE8 Records. 


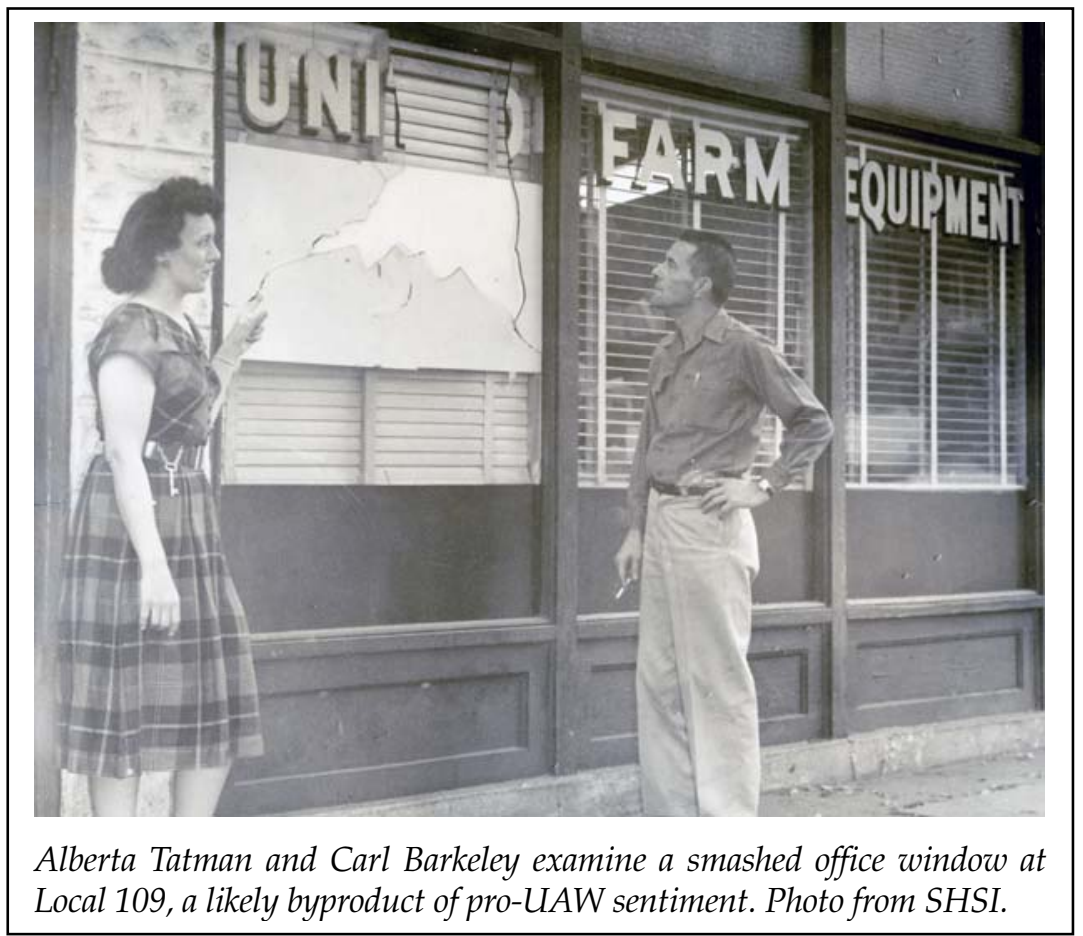

anything else until the layoffs came. When the layoffs came, of course people were rushing in to take stewards' jobs in order to have preferential seniority. So the UAW people, the people who were now UAW, told UAW people to take the FE steward job. So that nobody could trust anybody. ${ }^{57}$

Adding insult to injury, the two sides capped off the turbulent month with "the bloodiest union brawl in years in the Quad-Cities" after rival meetings on a Saturday morning. ${ }^{58}$ The disorder prompted the NLRB to take an unusual and extreme measure. Although the FE-UE's contract did not expire until 1955, the NLRB allowed an early election for Locals 104 and 106 , the latter of which had quit functioning entirely since the previous August. The NLRB ruling, which was delivered six months after the Saturday morning riot, allowed new elections,

57. Foster interview.

58. Moline Daily Dispatch, 8/29/1953. 


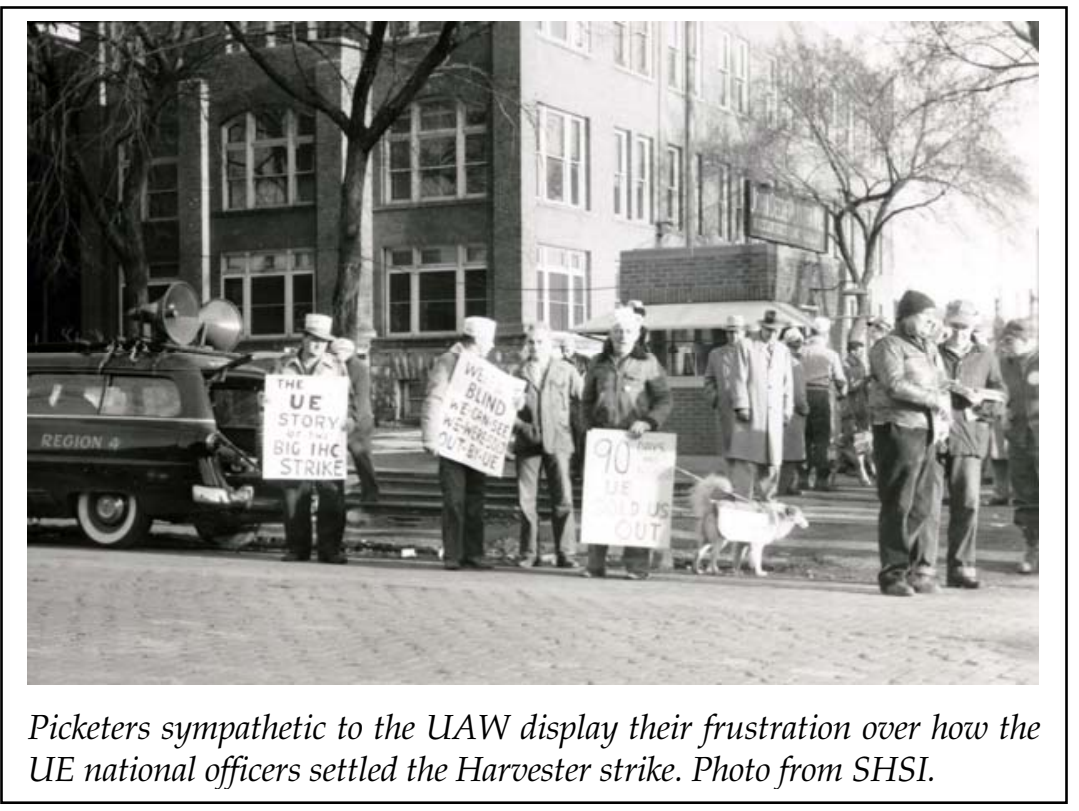

noting that a union contract is supposed to stabilize labor relations, which the current FE-UE contract obviously was not doing. In May 1954 the UAW won by a landslide in Harvester Locals 104 and 106. In much the same way, FE-UE's largest local in the Quad Cities, Local 109 in the Farmall division of International Harvester, voted UAW in early January $1955 .{ }^{59}$

After years of unsuccessful UAW raids, a combination of factors came together after 1953 to facilitate a UAW victory. The intensification of the Cold War, with the war in Korea and the increased visibility of HUAC hearings, changed the tenor of redbaiting, but red-baiting had been widespread since the early 1940s and the recent events probably did not change many minds that were not already made up on Communism and the FE-UE. The vast majority of FE-UE members were not Communists and, like Junior Kelley at John Deere and Co., trusted their leftwing leaders. Kelley never thought that anyone he knew was

59. The National Labor Relations Board, FE Local 104, Petitioner; Harvester Co., Employer - FE Local 106 Petitioner - Harvester Co., Employer, "108 NLRB No.91," UE8 Records; Foley, "Labor Union Jurisdictional Dispute," 7779,91 . The tally at Local 109 was 1,740 for the UAW to 760 for the FE. 
trying to "overthrow the government." Rather, he concluded that they were targets simply because they were "militant organizers doing the worker too much good."

Junior Kelley's impression that the Communist Party did not run the FE-UE is backed up by the best available facts. It is clear that many leaders in the FE and UE were either members of or sympathetic to the Communist Party (CP), but neither the FE nor the UE followed the trade union policy of the $\mathrm{CP}$ between 1949 and 1955. In fact, they often did the opposite. Immediately after its expulsion in 1949, the UE ignored the CP's calls to dissolve and infiltrate mainstream labor organizations. In 1950 CP Labor Secretary John Williamson wrote that "'decisive forces in the top leadership' of the UE were 'resisting an approach of real united action of U.E and I.U.E.,' and he condemned their 'blind factionalism. ' ${ }^{\prime 11}$ When the FE-UE locals did join mainstream labor unions, it was because of rank-andfile, not CP, demands for labor unity.

Infighting, not anti-Communism, was the true source of discontent driving members from these FE-UE locals. The union schism on the shop floor disrupted every aspect of union life. In such a working atmosphere, instructions from the national UE to simply remain loyal and stick it out no doubt rang hollow to many. Compounding the frustration with the national UE was the geographic isolation of the Quad Cities FE locals; many old FE members felt like second-class citizens in the UE. In this difficult situation, John Watkins and those who followed him into the UAW sought to get off of what appeared to be a sinking ship while they still had a voice in the matter.

THE FE eventually left the UE en masse and merged into the UAW in May 1955, but by then the Quad Cities locals in District 8 had already charted an independent course. At the beginning of 1955, the FE still represented some 2,000 workers in the Quad Cities. Those workers were employed principally at John Deere Plow Works, French and Hecht, and Herman Nelson Corpora-

60. Junior Kelley, interview by Gregory Zieren, Quad Cities, 8/1/1980, ILHOP. 61. Stepan-Norris and Zeitlin, Left Out, 305. 
tion. ${ }^{62}$ Spared the drama of the factional shop floor union fight that occurred at Harvester, these locals used the framework of their union, principally the UE's district and local bodies, to try to work out a resolution with the UE national officers that might achieve labor unity without disaffiliation.

In February 1955 the national UE General Executive Board (GEB) met expressly to address the accelerating loss of members and prospects for labor unity. The meeting did not go well. When the GEB set up a committee to explore the possibility of merging into the newly merged AFL-CIO, three top UE officers refused to participate. The meeting's failure to achieve any tangible results prompted delegates at the UE District 8 Convention the next month to pass a resolution that pushed the national officers to conduct promised "discussions for unity." ${ }^{63}$

The tension between the national UE office and District 8 came to a head in September at the 1955 national UE convention in Cleveland. In a lively debate on labor unity, District 8 President Don Harris noted that the rank and file's demand for unity had "finally reflected itself in the movement on the part of the leadership." The national UE was amenable to joining a unified labor movement. In early 1955 UE Director of Organization James J. Matles met with the president of the International Association of Machinists (IAM) to discuss a merger. The IAM refused a merger but would accept individual locals. Matles, willing only to accept a merger that would "give real meaning to the proposed unity," rejected the offer. To Matles, "real meaning" meant a merger that would retain the UE constitution and organizational structure - a merger comparable to the FE merger with the UE in $1949 .{ }^{64}$

62. “IAM, Membership Statistics for Local Lodges in the Midwest, 1956, 1960," International Association of Machinists and Aerospace Workers District Lodge 102 Records, 1941-1977, State Historical Society of Iowa, Iowa City. The total number of FE members in the Quad Cities decreased by about one-quarter between 1949 and 1955 due to both an economic recession beginning in 1953 and a miscalculation in postwar production on the part of the farm equipment companies. Gilpin, "Left by Themselves," 585, 586.

63. "Background to Merger," 4/1/1955, UE8 Records.

64. United Electrical, Radio and Machine Workers of America (UE), 20th Convention Proceedings, 1955, 155-56, 175-76; "General Executive Board Statement on Unity: Adopted February 18-19, 1955," UE8 Records. 
Given their desperate situation, delegates from District 8 were more amenable to compromise on the "real meaning" of labor unity. The decisive moment for disaffiliation came at the October 1955 District 8 convention in the Quad Cities. Attending were two of the three top UE officials, Albert J. Fitzgerald and Julius Emspak, who again made the case that the essence of rank-and-file democracy and militancy would not hold up unless the union merged into the mainstream together. In response, local delegates took turns hammering the national president for the lack of results at the union's top levels over the past six months. With the impending merger of the formerly antagonistic AFL and CIO looming large, the delegates noted the tragic irony of the national UE's concept of labor unity: "The policy of holding UE apart as an independent union in the face of the new labor federation is bearing fruit in the fragmentation of the UE by the very policy that speaks against fragmentation." To the disappointment of the national officers, the delegates voted 70-9 to leave the UE and merge on a local-by-local basis with either the IAM or UAW if the national union did not act by November $20 .^{65}$

THE NATIONAL UNION did not act, so by the end of 1955 the remaining FE-UE locals were left to engineer their disaffiliation "on a principled basis." The FE-UE locals in the Quad Cities voted independently to affiliate with the IAM (Machinists) over the UAW, even though the UAW had a much larger local presence in the Quad Cities and in the farm equipment industry nationally. The choice suggests that the FE-UE locals determined that the IAM was more accommodating to their principles. ${ }^{66}$

With roots in craft unionism and the AFL, the Machinists had been slow to organize industrial workers. Between 1912 and 1926 the union's socialist-influenced leader, William Johnston, expanded the organization's decentralized structure to accommodate rank-and-file democracy and local autonomy in the

65. “Labor Unity: Annual UE District \#8 Convention, Oct. 29-30, 1955, Rock Island, Illinois," UE8 Records; "Notes on Unity Discussion: Dist. 8 Convention, Oct. 30, 1955, Rock Island," UE8 Records; "Background to Merger."

66. Feurer, Radical Unionism in the Midwest, 229. 
union. The Quad Cities, in particular, were a hotbed of socialist labor radicalism during that period. ${ }^{67}$ These structural reforms stayed in place when the Machinists began to organize along a joint craft/industrial basis in 1937. By the 1950s, the IAM had grown to 500,000 members and was unique among its competitors; its "emphasis on local autonomy," historian Mark Perlman notes, "sets the IAM apart from other large industrial unions in manufacturing. Unlike the steelworkers' or the autoworkers' locals, the local lodges of the IAM still maintain considerable bargaining power and autonomy." ${ }^{68}$

Despite its history of progressivism and socialism, the IAM took a hard anti-Communist line in the 1950s. Unlike the UAW, however, the Machinists could transcend red-baiting and realistically market themselves as a union with "the most democratic procedures in the country." Literature produced during raids pointed out that "in IAM-AFL every single member votes in the election of President and Secretary-Treasurer of the International Union," whereas in the UE, the top three officials were elected by delegates at the national conference, or, as the Machinists put it, "handpicked by a machine controlled convention dominated by Communists!"

Just as James J. Matles was attracted to the possibility of merging the UE with the Machinists as a whole in early 1955, so too were militant local leaders in the Quad Cities out shopping for a new union. Wayne "Banjo" Smith, president of Local 150 at John Deere Plow, defended the FE-UE until he cast one of the seven dissenting votes to disaffiliate from the UE. After years of fighting off the UAW, Smith recalls, "I had it burned into my

67. John H. M. Laslett, Labor and the Left: A Study of Socialist and Radical Influences in the American Labor Movement, 1881-1924 (New York, 1970), 144-91; David Montgomery, The Fall of the House of Labor: The Workplace, the State, and American Labor Activism, 1865-1925 (New York, 1987), 281-84; William H. Cumberland, "The Davenport Socialists of 1920," Annals of Iowa 47 (1984), 45174; idem, "The Red Flag Comes to Iowa," Annals of Iowa 39 (1966), 441-54.

68. Mark Perlman, Democracy in the International Association of Machinists (New York, 1962), 30. See also idem, The Machinists: A New Study in American Trade Unionism (Cambridge, MA, 1961); and Nelson Lichtenstein, The Most Dangerous Man in Detroit, 198.

69. “IAM: Standard of Sound Unionism," IAM pamphlet, UE8 Records; "What's UE Afraid of?" IAM handbill, UE8 Records. 
heart that I wanted no part of the UAW," so he proceeded to help guide his local toward the Machinists. Leaders of Local 150 had met earlier in the year with officials from the UAW and IAM to discuss terms for affiliation and found that the IAM offered terms more congruent with FE-UE-style unionism. For example, in the UAW, "the International must be asked for authorization to strike," whereas in the IAM, a local is free to call its own strikes and must only notify the Grand Lodge and comply with the TaftHartley Act. In addition to the broad conditions for affiliation set at the District 8 Conference, each local was allowed to draft conditions of its own. And unlike the UAW, the IAM agreed to all of Local 150's 11 conditions, several of which guaranteed a foundation for rank-and-file democracy and local autonomy. Another militant FE-UE local leader, Carroll Wright of Local 822 at Herman Nelson Co., proclaimed that "I was instrumental .. . about getting the majority of the people in this area to go Machinist." Wright recalled telling the rank and file at the remaining FE-UE locals that "we had been guaranteed full autonomy as far as the Machinists, that we'd make our own decisions. ... . we'd maintain the same set-up we had before as far as our stewards, our chief steward, our negotiating committees, shop committees. You know, none of that would be changed. And it wasn't." ${ }^{70}$

The Machinists offered an attractive alternative for those looking to avoid the bureaucracy of the UAW and the myriad problems that plagued the FE-UE. It is telling that when these remaining FE-UE locals were given a reprieve from raids and the dual unions on the shop floor and allowed an informed decision between the UAW and the IAM, they chose to go with the Machinists. The Quad Cities locals were not the only UE defectors to choose the IAM. District 8 was the first UE district to

70. Ibid., 48; "Special Meeting of Local 150 UE, Executive Board and Grievance Committee with the UAW," 2/3/1955, meeting minutes, UE8 Records; "Special Meeting of Local 150 UE, Executive Board and Grievance Committee with Hal Rouch and Christenson, Business Agents of the I.A.M. for the Purpose of Probing Their Union for Possible Affiliation," 1/20/1955, meeting minutes, UE8 Records; "Statement of Policy of Merger Committee, John Deere Plow Works, as Adopted by the Membership at a Special Meeting Held at the Swedish Olive Hall on __ 1955," UE8 Records; Carroll Wright, interview by Paul Kelso, Quad Cities, 6/16/1980, ILHOP. 
disaffiliate, but was soon followed by three more: UE Districts 3 and 7 went into the IAM, and District 9 split between the IAM, UAW, and the International Brotherhood of Electrical Workers. ${ }^{71}$

If the IAM had actively contested elections from the beginning at International Harvester, it might have diminished the strong support for the UAW. But the IAM had mostly stayed out of the UAW/FE-UE conflict. Burton Foster likely represents many Harvester workers who joined the UAW simply to get out of the UE. Foster recalled, "I had nothing against the IAM, except that I felt that Harvester workers were organized basically almost totally by UAW." ${ }^{72}$

The move of the FE-UE Harvester locals to the UAW cannot be read as a rejection of militant and democratic unionism. John Watkins's labor militancy never wavered as he led the charge toward the UAW at Harvester. ${ }^{73}$ Rather, Watkins's case suggests that he was simply the first in a long line of militant union leaders who sought to get out of the UE with the best deal they could.

FE-UE WORKERS who joined the Machinists in 1955 were able to retain their local leaders and democratic autonomy, but over time those rights meant less and less as the unified labor movement of 1955 failed to live up to its lofty expectations. Carroll Wright, who served in the Machinists well past 1955, reflected on the decline of both the social and economic aspects of trade unionism in the Quad Cities:

You talk to guys in the plant that had worked under FE, . . UE and then afterwards, and had any real knowledge of the working conditions. . . . I've had hundreds of them tell me. It was a mistake.

71. Filippelli and McColloch, Cold War in the Working Class, 189. That the IAMAFL was so flexible in accommodating militant unionists during the 1950s suggests the need to continue to rethink the legacy of conservative craft unionism in the twentieth century. See Christopher L. Tomlins, "AFL Unions in the 1930s: Their Performance in Historical Perspective," Journal of American History 65 (1979), 1021-42; and Dorothy Sue Cobble, Dishing It Out: Waitresses and Their Unions in the Twentieth Century (Urbana and Chicago, 1991).

72. Tri-City Labor Review, 10/31/1952; Foster interview.

73. Wayne "Banjo" Smith, interview by Paul Kelso, Quad Cities, 5/19/1978, ILHOP. 
... It's big business now, I'll tell you, just like you're a number. You go in there and you put your time in. And this is true everywhere. ... Herman Nelson plant, like I say, we were a close group. Right now, hell. ${ }^{74}$

In many respects, the UE's national leadership in 1955 had foreseen the false promise of a powerful united labor movement whose bureaucratic structures capitalized on years of workers' organization and came to eclipse their democratic voice. As Carroll Wright's testimony suggests, the lack of such rank-andfile engagement that came to define the new industrial unions of the AFL-CIO hastened a breakdown in social cohesion and left many committed union men feeling "like a number" in their unions as well as in their jobs. Indeed, the principled conditions set by individual FE-UE locals failed to make much of an impact on the larger labor unions, and the desertion of those and other locals left the UE a crippled union without the numerical clout to affect the tenor of the labor movement nationally.

In hindsight, the conflict between UE locals and the national body in 1955 reflects a dire situation for locals and a national union backed into a corner. On the one hand, the national officers may not have appreciated just how difficult it was to stand by the UE when bitter union factions on the shop floors caused union business to cease functioning. On the other hand, the Quad Cities locals may not have appreciated that the only options available for the UE to enter mainstream labor entailed ceding UE's core ideals. Instead, the UE chose to continue its difficult independent course and thus remains a small but progressive voice in the labor movement to this day. ${ }^{75}$

Yet it is also clear that decisions made by the UE between 1949 and 1955 precipitated its decline in places such as the Quad Cities. Critical misreadings of the cultural and social climate as well as poorly gauging the willingness of labor's rank and file to resist the CIO's conservative course certainly contributed to the union's difficult situation. The hope of the UE to pursue the path of successful independent unions such as the United Mine

74. Wright interview.

75. In recent years, the UE has reestablished a presence in Iowa by broadening its jurisdictional reach to public sector employees, notably among state social workers and graduate students at the University of Iowa. 
Workers and the Machinists was not tempered by the reality of new antilabor legislation, the difficulty in maintaining its politically radical stance in the Cold War climate, or the ideological resonance that a united labor movement would have within its constituency. Indeed, the social conservatism of union members in the urban North became only more pronounced and complex for labor unions with the cultural upheaval spawned by the civil rights movement in the 1960s and the populist racism that ignited George Wallace's presidential run in $1968 .^{76}$

Ultimately, the old FE locals merged with mainstream labor for reasons similar to those that motivated the FE's merger with the UE in 1949. Beginning in 1953 at International Harvester, FEUE local leaders in the Quad Cities responded to a rank-and-file call for labor peace and unity and proceeded with difficult but necessary compromises. They did this not because red-baiting had finally made an impression or because they had embraced bureaucratic unionism, but rather because they saw in mainstream labor organizations the practical potential to continue their effective tradition of rank-and-file democracy and militancy, the only kind of unionism they had known, which the national UE could promise but no longer provide.

76. See, for example, Kazin, Populist Persuasion, 221-42; and Lichtenstein, Most Dangerous Man in Detroit, 427-28. 